\title{
Evaluation the Impact of Capital Adequacy on the Return on Equity of Islamic Banks in Gulf Cooperation Council
}

\author{
Khaled Naser Al-khawaldah", Alaaeddin Awad Al-tarawneh, Ghazi-alassaf \\ School of Business, University of Jordan, Amman, Jordan \\ Email address: \\ Knk khaled@hotmail.com (K. N. Al-khawaldah) \\ ${ }^{*}$ Corresponding author \\ To cite this article: \\ Khaled Naser Al-khawaldah, Alaaeddin Awad Al-tarawneh, Ghazi-alassaf. Evaluation the Impact of Capital Adequacy on the Return on \\ Equity of Islamic Banks in Gulf Cooperation Council. International Journal of Business and Economics Research. \\ Vol. 9, No. 4, 2020, pp. 207-210. doi: 10.11648/j.ijber.20200904.17
}

Received: May 1, 2020; Accepted: June 8, 2020; Published: July 4, 2020

\begin{abstract}
The purpose of this study examines the effect of the capital adequacy on the return on equity for the largest 16 Islamic banks in gulf cooperation council in terms of market value, using panel data analysis during the Period (2010-2014) and the effect the size, inflation, and GDP as a control variables, Also to explain how Islamic banks comply with international solvency standards (Basel), and the extent to which those standards with special nature of the Islamic banks and their impact on earnings of these banks. The study data collected from published annual reports for banks The capital adequacy is the main tool to measure the bank's ability to meet its obligation and liabilities It is a one of the risk exposure scales of banks, such as credit risk, market risk, and operational risk. Islamic banks have special standards issued by the accounting and auditing organization for Islamic financial institutions (AAOIFI) and the council of Islamic financial services board (IFSB). The study found that there is a significant relationship between capital adequacy and return on equity in the absence and in the presence of control variables and the relationship was negative, size has a statistically significant positive effect on the return on equity, inflation has a statistically significant negative effect on the return on equity, GDP has a statistically significant positive effect on the return on equity.
\end{abstract}

Keywords: Capital Adequacy, Return on Equity, Islamic Banks

\section{Introduction}

One of the biggest achievements in the financial sector in the economy of gulf countries has been the upward review of the capital base for banks. This resulted in stronger and more flexible financial institutions.

Capital adequacy for banks and financial institutions is a ratio for its capital to its assets; Capital adequacy is one of measurements of financial strength for the banks and security firms. The Islamic banks are spread in the world and they form a big part from the banking sector worldwide. Islamic banks work under the basics of Islamic rules, in principle they conduct business under the Islamic regulations that are derived from the "Holy Quran" and prophet "Muhammad" [1].

The standards for capital adequacy that were set by Basel committee of the Bank for International Settlements have been introduced since 1988, the minimum required capital of banks is equal to 8 percent of their assets, in 2004 Basel II was established, and argued that the sensitivity of risk for capital requirements should be increased and that greater use should be made of the estimation risk produced by the internal systems of banks. The revisions which have sparked controversy are being considered by supervisors of national banks and implementation at the end of 2007. The original Basel III rule from 2010 required banks to hold $4.5 \%$ of common equity (up from $2 \%$ in Basel II) of risk-weighted assets [2].

In general banks predict that their normal earnings can restitution their losses, but there may be some unexpected losses that cannot be realized by their normal earnings.

Capital comes in handy on such abnormal loss cases to cushion the losses. In this approach capital can be considered as an insurance tool. Capital adequate in banking is a confidence corroborates, for the customers, the public, and for the regulatory authority, that way the bank will remain, in continuous existence.

However, the studies affirm the profitability determined by 
capital adequacy of banks [3].

The profit is the tool that help the firm to survive, thus profitability have a main role to achieve to funds supply in terms of bank deposit on advantageous terms. The importance of bank Profitability has made academics, researchers, banks management, shareholders and banks regulatory authorities develop enormous interest based on the factors that determines the profitability of banks [4].

The standards for the Islamic banks were discussed in the Accounting and Auditing Organization for Islamic Financial Institutions and developed in the Council of Islamic Financial Services Board; these two committees set the special standards for all Islamic banking sectors [5]. The Capital Adequacy Framework for Islamic Banks was first issued on 4th August, 1989, along with amendments and additional requirements introduced subsequently. This document was last updated on 28th November, 2012. Islamic banking system of work is different from commercial banking system; because its assets are distinct from those of commercial counterparts [6].

\section{Literature Review}

This section reviews empirical studies that discussed the relationship between capital adequacy the earnings ratios and controls variables for financial institutions.

Bateni L. \& others argued that the Capital adequacy and sufficient capital are the most primary requirements for banks and financial institutions; they became the most significant criteria for depository institutions that every bank must be sure that it has a balance between the capital and the risk of its assets to insure the continuation of its work they Found a negative relationship between capital adequacy ratio and size, and a positive relationship between capital adequacy ratio and Loan Asset Ratio, (ROE), (ROA), (EQR), Risk Asset Ratio (RAR) have no effect on capital adequacy ratio [7]. Rufo's M. \& John P. investigate in thiar study the impact of credit risk on capital adequacy. The sample consisted banks in Philippines. the study indicated that capital adequacy has no significant impact on the banks' profitability in Philippines [8]. Shaikh S. \& Jalbani A. they argued that there is a strong positive relation between Return of Equity (ROE) and both Islamic Banks and commercial banks, proving that both are profitable and have an adequate risk management system to run the day-to-day operations smoothly [9].

The researcher calculated the capital adequacy ratio for Islamic banking in Pakistan under the Basel-II and Islamic Financial Services Board (IFSB) standards. Jabeen Z. \& Khan M. explored the result is that the Islamic banks are more flexible and loss absorbing due to loss and profit sharing method. Basel-II gives the banks strong basis of prudent capital regulation, and develops risk management as well as financial stability [10].

In the study for Boshkosa, M. he studied the profitability of Macedonian banking sector. The study has found that the higher capital adequacy ratio is the more stable the sector will be, and that there is positive impact between capital adequacy ratio and the profitability [11].

M. Jaradat \& M. ALkhazaleh found that there is no significant effect of the capital adequacy on the profitability of Jordanian commercial banks listed on the Amman Stock Exchange [12].

Goddard J. \& others finding that the bank's size has had a positive impact on the banking sector performance of five European countries over the period of 1990s [13].

Samina R. \& Ayub M. they found that there is a significant effect of assets size, leverage ratio, credit risk and interest rate on the profitability measures ROE and ROA [14]. Hassan M. \& Bashir A. explored that generating high profitability, higher growth rate of GDP seems to have a positive impact on the performance measures, on the other hand the Size of the banking system has negative impact on the bank profitability except net non-interest margin [15].

Ostadi H. \& Monsef N. They found that positive relationship between the bank size and bank concentration on the profitability measured by ROE and ROA, and bank deposits, bank size, bank capital [16]. Al Tamimi, H. found that bank portfolio, Islamic Banking and Finance bank size have a highly significant relation with ROA and ROE for the National bank's performance [17]. AlSabbagh N. \& Magableh A. was found a negative significant relationship between capital adequacy ratio and size in the Islamic banks [18]. Abusharba T. \& others found that there is a positive relationship between capital adequacy ratio (CAR) and profitability and liquidity in Indonesian Islamic and Commercial Banks. [18].

Reynolds S. \& others The researchers conducted a study for banks in Asian countries during (1987-1997); they found that there is a positive relationship between loan preference and banks size, but the capital adequacy has a negative relationship with bank's size, so large banks have a small capital adequacy ratio [20]. Perry, P. found that the inflation and interest rates are affected by the profitability, if the inflation is anticipated and the interest rates are adjusted, a positive effect will result [21].

\section{Data and Methodology}

This study examined the relationship between Capital Adequacy and Return on Equity as empirical evidence from some of the Islamic Banks in the GCC period (2010-2014). Consequently, the source of the data is annual reports for banks. The regression models that used to test the study hypothesis are [22]:

$$
\mathrm{ROE}=\mathrm{a}+\beta 1 \mathrm{CA}+\beta 2 \text { size }+\beta 3 \text { inflation }+\beta 4 \mathrm{GGDP}+\varepsilon i .
$$

The main hypothesis for this model to achieve the objective of study: Ho: There is no statistically significant effect between Capital Adequacy and Return on Equity for Islamic banks.

The study data collected from annual reports for banks and entered as well as analyzed through using the E-views program. The following tests are used to achieve the study goals. 
Table 1 presents descriptive statistics of the dependent and control variables used in this study. ROE is the dependent variable measured by net income divided by total equity, where size (Ln total assets), inflation is the rate of inflation, GDP is the real GDP growth rate, and CA is independent variable and its measured by divided equity by total assets.

Table 1. Descriptive statistics.

\begin{tabular}{llllll}
\hline & CA & ROE & SIZE & INF & GGDP \\
\hline Mean & 0.207 & 0.109 & 16.6 & 2.58 & 5.17 \\
Median & 0.18 & 0.099 & 16.7 & 2.73 & 4.57 \\
Maximum & 0.75 & 0.677 & 18.6 & 5.82 & 19.6 \\
Minimum & 0.12 & -0.213 & 13.9 & -2.43 & -2.37 \\
Std. Dev. & 0.086 & 0.105 & 1.18 & 1.77 & 4.31 \\
Observations & 77 & 80 & 80 & 80 & 80 \\
\hline
\end{tabular}

\section{Empirical Results}

\subsection{Correlation Matrix}

The table below shows the correlation matrix for the study variables. It is evident that the highest correlation is between ROE and GDPG $(r=0.220)$. Whereas the lowest correlation is between ROE and CAR $(r=-0.132)$. Additionally, it can be seen from the table that there is a negative correlation between INF and ROE $(r=-0.060)$. However, there is a positive relationship between SIZE and ROE $(r=0.161)$ and also a positive relationship between LDR and $\operatorname{ROE}(\mathrm{r}=$ 0.157). That means no multicollinearity problem.

Table 2. Correlation matrix.

\begin{tabular}{lllllll}
\hline & ROE & CAR & GDPG & INF & SIZE & LDR \\
\hline ROE & 1 & & & & & \\
CAR & -0.132 & 1 & & & & \\
GDPG & 0.220 & 0.038 & 1 & & & \\
INF & -0.060 & 0.123 & -0.033 & 1 & & \\
SIZE & 0.161 & -0.301 & -0.082 & 0.139 & 1 & \\
LDR & 0.157 & -0.146 & 0.221 & -0.230 & -0.0199 & 1 \\
\hline
\end{tabular}

\subsection{Fixed or Random Test}

Shows cross section fixed effects. It is evident that the Fstatistics of cross section is (28.05) and it is significant at ( $\alpha$ $\leq 0.05)$.

\subsection{Hausman Test}

The Correlated Random Effects (which is examining the cross section of random effects). It can be seen that the ChiSquared statistics value is (2.79) and it is not significant at $(\alpha \leq 0.05)$ with 4 degree of freedom.

\subsection{Estimation Results}

The following is the estimation results of the study model:

Table 3. Estimation Results.

\begin{tabular}{|c|c|c|c|c|}
\hline Variable & Coefficient & Std. Error & T-Statistic & Prob. \\
\hline $\mathrm{C}$ & -0.065 & 0.077 & -0.852 & 0.398 \\
\hline CAR & -0.119 & 0.054 & -2.18 & 0.033 \\
\hline GDPG & 0.003 & 0.001 & 3.98 & 0.0002 \\
\hline INF & -0.005 & 0.002 & -2.58 & 0.012 \\
\hline SIZE & 0.012 & 0.004 & 2.76 & 0.008 \\
\hline \multicolumn{5}{|l|}{ Effects Specification } \\
\hline \multicolumn{5}{|c|}{ Cross-section fixed (dummy variables) } \\
\hline R-squared & 0.933 & Mean dependent var & & 0.391 \\
\hline Adjusted R-squared & 0.912 & S.D. dependent var & & 0.335 \\
\hline S.E. of regression & 0.076 & Sum squared resid & & 0.327 \\
\hline F-statistic & 42.2 & Durbin-Watson stat & & 1.96 \\
\hline Prob (F-statistic) & 0 & & & \\
\hline \multicolumn{5}{|l|}{ Unweighted Statistics } \\
\hline R-squared & 0.597 & Mean dependent var & & 0.109 \\
\hline
\end{tabular}

It is evident from the table above that the value of $\mathrm{R}^{2}=$ 0.933 . This means that the independent variables can account $(93.3 \%)$ of the Return on Equity variation. It is noticed that the value of adjusted $R^{2}$ is very close to the value of $R^{2}$. If the adjusted $R^{2}$ is excluded from $R^{2}(0.933-0.912)=0.022$. This little shrinking (0.022) means that if the model has been fitted when the whole population participates in the study, there will be 0.022 less variance in the outcome.

Also, it can be seen that F-value is 42.2 and it is significant, at $(\alpha \leq 0.05)$. This indicates that the independent variables have a significant effect on $\operatorname{ROE}(\alpha \leq 0.05)$.

Moreover, the results show that CAR has a significant effect on ROE, where the P-value is significant at $(\alpha \leq 0.05)$ and the tstatistics is lower than the t-tabulated. Also, the above results reveal GDPG has a significant effect on ROE P-value is (0.0002) and the t-calculated is higher than the t-tabulated. Additionally, the results show that the Sig-value of INF is $(0.0123)$ and it is 0 significant at $(\alpha \leq 0.05)$ and the t-calculated is lower than the t-tabulated. This implies that INF has a significant effect on ROE. Furthermore, the result shows that the Sig-value of size is (0.008) and it is significant at $(\alpha \leq 0.05)$ and the $\mathrm{t}$-calculated is higher than the t-tabulated. Overall, both CAR and INF have a negative effect on ROE, while both SIZE and GDPG have a positive effect on ROE.

\section{Conclusion}

The main purpose of this study is to examine the 
relationship between capital adequacy and return on equity for a sample of the Islamic Banks in Gulf countries. Based on the study analysis, the following conclusions and recommendations are proposed:

The study found that there is a statistically significant negative effect for capital adequacy on return on equity. This indicates that the capital adequacy requirement limits the risk of investment for a bank and therefore affects its capacity to achieve a target level of profitability. This result is consistent with the study [23] "Capital Adequacy, Cost Income Ratio and the Performance of Saudi Banks (2007-2011)".

The study found that SIZE has a statistically significant positive effect on the return on equity, which indicates that larger banks achieve a higher ROE. Also, the positive and significant coefficients of the variable asset size provide evidence for the scale theory of economies. This result is consistent with the study [24].

The study found that INF has a statistically significant negative effect on ROE; this indicated that the increase of the costs in the country will decrease the earning rate.

Moreover, the study found that the GDP has a statistically significant positive effect on the return on equity. This indicated that when GDPG rate increase the profitability for banks will increase and so the ROE will increase.

\section{References}

[1] Antonio, Muhammad Syafi'i. (2008). "Islamic Micro finance Initiatives to Enhance SMEs" in Expressing Islam: Religious Life and Politics in Indonesia, by Greg Fealy and Sally White, pp 251-266. Panjang: Institute of Asian studies.

[2] Hamdy Hesham. (2012), Basel II to Basel III: changes and requirements.chief risk officer, Arab international bank Nairobi.

[3] Gul, S., Irshad, F., andZaman, K. (2011). Factors affecting bank profitability in Pakistan. The Romanian Economic Journal, 39 (14), 61-89.

[4] Athanasoglou, P., Sophocles, B., and Matthias, D. (2005). Bank-specific, industry specific and exchange rate, interest rate, inflation rate and GDP fluctuation determinants of bank profitability. Working paper, Bank of Greece.

[5] Saeed, H., and Ali, A. (2014). Reality and safety of application in the capital adequacy of Islamic banks. $1^{\text {st }}$ international Islamic finance conference.

[6] Malaysia, B. N. (2012). Capital Adequacy Framework for Islamic Banks (Capital Components). Kuala Lumpur: Bank Negara Malaysia.

[7] Bateni, L., Vakilifard, H., and Asghari, F. (2014). The influential factors on capital adequacy ratio in Iranian banks. International Journal of Economics and Finance, 6 (11), 108.

[8] Rufo's, M. and John, P. (2017) The effect of credit risk and capital adequacy on the profitability of rural banks in the Philippines.

[9] Sheik, S. A., \& Ali, A., (2009). Risk management in Islamic and conventional banking: a differential analysis. Journal of Independent Studies and Research 7: 2.
[10] Khan, S., and Jabeen, Z. (2011). Comparative study of Assessment of Capital Adequacy Ratio (CAR) for Islamic Banks in Pakistan under Basel II and IFSB formulae for Capital Adequacy. International Conference on Islamic Economics and Finance, Qatar National Convention CenterDoha, Qatar.

[11] M. Jaradat \& M. ALkhazaleh The Effect of Liquidity, Administrative Efficiency and Capital Adequacy on the Profitability of Jordanian Banks listed on the Amman Stock Exchange, International Journal of Academic Research in Accounting, Finance and Management Sciences Vol. 8, No. 4, October 2018, pp. 183-194.

[12] Boshkosa, Meri. (2013), the profitability of Banking sector in Republic of Macedonia, International journal of economics and finance, vol 5 , no. 3 .

[13] Goddard, J., Molyneux, P., and Wilson, J. O. (2004), The profitability of European banks Across - sectional and dynamic panel analysis. The Manchester School, 72 (3), $363-$ 381 .

[14] Samina, R., and Ayub, M. (2013). "The impact of Bank Specific and Macroeconomic Indicators on the profitability of Commercial banks". Roman Economic Journal, Department of International Business and Economics from the Academy of Economics Studies Bucharest, 10 (47), 91-110.

[15] Hassan, M. K., \& Bashir, A. H. M. (2003, December). Determinants of Islamic banking profitability. In 10th ERF annual conference, Morocco (pp. 16-18).

[16] Ostadi, H., and Monsef, N. (2014), Assessing the Impact of Bank Concentration and Liquidity of Refah Bank Branches on Profitability during the Period 1983-1990. International Journal of Human Resource Studies, 4 (1), Pages-248.

[17] AlTamimi, H. A. H. (2005), Factors Influencing Individual Investor Behavior: An Empirical Study of the UAE Financial Markets. The Business Review, 5 (2), 225-233.

[18] AlSabbagh, N. M., and Magableh, A. H. (2004). Determinants of capital adequacy ratio in Jordanian banks (Doctoral dissertation).

[19] Abusharba, T., M., et al. (2013), Determinants of capital adequacy ratio (CAR) in Indonesian Islamic Commercial Bank, Global Review of Accounting and Finance.

[20] Reynolds SE, Ratanakomut SG, James Gander (2000), Bank financial structure in pre-crisis East and South East Asia. J. Asian Econ., 11 (3): 319-331.

[21] Perry, P. (1992), Do Banks Gain or Lose from Inflation?Journal of Retail Banking, Vol. 14, No. 2, 25-30.

[22] Berger, A. N. (1995), The Relationship between capital and earnings in Banking. Journal of Money, Credit and Banking, 27, 432-456.

[23] Almazari, A. A. (2013). Capital Adequacy, Cost Income Ratio and the Performance of Saudi Banks. International Journal of Academic Research in Accounting, Finance \& Management Sciences, 3 (4), 284-293.

[24] Anbar, A., and Alper, D. (2011). Bank specific and macroeconomic determinants of commercial bank profitability: Empirical evidence from Turkey. Business and Economics Research Journal, 2 (2), 139-152. 